\section{Intake of fat and fiber-rich foods according to socioeconomic status: the 11-year follow-up of the 1993 Pelotas (Brazil) birth cohort study}

\author{
Consumo de alimentos com alto teor de gordura \\ e fibras entre adolescentes, segundo posição \\ socioeconômica: a visita de 11 anos da \\ coorte de nascimentos de Pelotas, \\ Rio Grande do Sul, Brasil, 1993
}

\author{
${ }^{1}$ Faculdade de Nutrição, \\ Universidade Federal de \\ Pelotas, Pelotas, Brasil. \\ 2 Programa de Pós-graduação \\ em Educação Física, \\ Universidade Federal de \\ Pelotas, Pelotas, Brasil. \\ 3 Programa de Pós-graduação \\ em Epidemiologia, \\ Universidade Federal de \\ Pelotas, Pelotas, Brasil. \\ Correspondence \\ M. B. Neutzling \\ Departamento de Nutrição, \\ Faculdade de Nutrição, \\ Universidade Federal de \\ Pelotas. \\ Campus Universitário sn, \\ Pelotas, RS \\ 96010-900, Brasil. \\ mneutzling@terra.com.br
}

\begin{abstract}
This study describes the food intake of adolescents participating in the 1993 birth cohort from Pelotas, Southern Brazil, according to socioeconomic position. We carried out a cross-sectional analysis of data collected in the 2004-2005 follow-up visit. Food intake in the previous year was evaluated using the Block questionnaire. Socioeconomic status was evaluated based on an assets index, divided into quintiles. Foods with the highest frequency of daily intake were white bread (83\%), butter or margarine (74.6\%), beans (66.4\%) and milk (48.5\%). Intake of butter or margarine, bread, and beans was more frequent among poorer adolescents, and the inverse was true for milk. Intake of fruits and vegetables was low in all socioeconomic strata, but particularly low among the poor. In early adolescence, all socioeconomic groups showed high consumption of foods rich in fat and low consumption of foods rich in fiber.
\end{abstract}

Eating; Food Habits; Socioeconomic Factors; Adolescent; Cohort Studies

\author{
Marilda B. Neutzling 1,2 \\ Cora Luiza Araújo 1,3 \\ Maria de Fátima A. Vieira 1,3 \\ Pedro C. Hallal 2,3 \\ Ana M. B. Menezes 3 \\ Cesar G. Victora ${ }^{3}$
}

\section{Introduction}

Diet is an important associated factor for a number of highly prevalent complex chronic diseases, such as obesity, type-2 diabetes, and cardiovascular disease 1 . Since dietary habits are formed during early life and tend to remain unaltered throughout adulthood 2,3, identifying factors that influence food intake among youths is becoming a topic of growing interest. However, population-based studies investigating the association between food intake and socioeconomic status among Brazilian adolescents are rare.

Recent review 4 and metanalysis 5 studies conducted in Europe have examined the association between dietary habits and schooling and occupation - used as indicators of socioeconomic status - among adults. Irala-Estévez et al. ${ }^{4}$ found unhealthy dietary patterns among adults of lower socioeconomic status, and higher intake of fruit and vegetables among the higher strata. On the other hand, Sanchez-Villegas et al. 5 concluded that intake of cheese was higher among subjects of higher socioeconomic level, although no differences were detected with respect to milk.

Several studies 6,7,8,9 have detected associations between family socioeconomic status and the intake of specific foods among adolescents. In 2003, Serra Majem et al. 7, studying a representative sample of the Spanish population aged two to 24 years, found that family socioeconomic status influenced the intake of meats, fish, fruits, 
vegetables, yoghurt, and cheese. In a populationbased study carried out in Australia, Giskes et al. 6 found that intake of fruit and vegetables among adults and adolescents was positively associated with family income. In Brazil, a cross-sectional study of adolescent students from private and public schools in Campina Grande, in the country's Northeastern Region, carried out in 2007 by Nunes et al. 9 , showed higher frequency of unhealthy dietary habits (daily intake of soft drinks, sweets, and chips) among adolescents from higher socioeconomic classes. In Pelotas, Southern Brazil, Neutzling et al. 8 found that socioeconomic level and maternal schooling were associated with prevalence of diets rich in fat and poor in fiber among adolescents from the 1993 Pelotas birth cohort study.

Studies investigating food intake in populations are often focus on macronutrients or on micronutrients associated with certain diseases 10,11. However, more recently, the Dietary Guide for the Brazilian Population 12 has emphasized its recommendations regarding the intake of foods rather than that of specific nutrients. One of the advantages of analyzing foods or food groups is the possibility to evaluate dietary behaviors, and consequently to propose modifications in intake patterns directly targeting the population 13 .

The present study describes the food intake patterns of 11-year-old adolescents from the 1993 Pelotas birth cohort study, according to socioeconomic status, to provide subsidy to dietary recommendations.

\section{Methods}

All hospital births taken place in the city of Pelotas in 1993 were identified. While still in the hospital, we administered a questionnaire to mothers, and newborn babies were weighed and measured. Subsamples of this population were visited at ages 1, 3, and 6 months and 1, 4, 6, and 9 years. In 2004-2005, we attempted to trace all cohort subjects for a further follow-up, the details of which are described elsewhere 14 .

Frequency of intake of different foods was obtained using a questionnaire developed by Block, which is divided into two sections 15 . The first section, comprising 15 food items, aims to identify the frequency of intake of foods rich in fat. The second section, comprising 9 items, investigates the intake of foods rich in fiber. Independent variables studied included sex, family socioeconomic status (assets index, built based on factorial analysis and divided into quintiles), and mother's schooling. Greater details on these variables are available in another article in this supplement 16 .

We carried out descriptive analysis of the frequency of intake of different foods according to sex, assets index, and mother's schooling. Significance was determined using chi-squared tests for heterogeneity or linear trend. When comparing food intake according to socioeconomic status, we used the slope index of inequality, which is based on a regression model and presents differences between extreme percentiles considering data from all groups rather than from the extremes only 17 .

Adolescents were weighed and measured using portable scales with $100 \mathrm{~g}$ precision (SECA, Birmingham, UK) and aluminum anthropometers with $1 \mathrm{~mm}$ precision. Tricipital and subscapular skinfolds were also measured using a Cescorf caliper with $0.5 \mathrm{~mm}$ precision (Cescorf Equipamentos para Esporte Ltda., Porto Alegre, Brazil). We calculated the body mass index (BMI) and classified the nutritional status of subjects according to the criteria proposed by the World Health Organization (WHO) ${ }^{18}$, which define as at risk of overweight adolescents with $\mathrm{BMI} \geq$ percentile 85 and as obese those with $\mathrm{BMI} \geq$ percentile 85 and tricipital and subscapular skinfolds $\geq$ percentile 90. Sedentariness was defined as performing less than 300 minutes of physical activity per week, according to current recommendations for adolescents 19 .

The study protocol was approved by the Research Ethics Committee of the School of Medicine, Federal University in Pelotas. Mothers or caretakers signed a term of consent allowing the youth to participate in the study.

\section{Results}

The study sample $(\mathrm{N}=4,452)$, when added to the 141 cohort members known to have died between 1993 and 2004, represents $87.5 \%$ of the original cohort. As seen in Table 1, roughly half (50.8\%) the adolescents were male. The number of subjects in each quintile of the assets index was $863,851,857,857$, and 856 , in increasing order of wealth. At age 11 years, $23.2 \%$ of adolescents were at risk of overweight and $58.2 \%$ were sedentary. Approximately $26 \%$ of mothers had less than five years of schooling, $43 \%$ had five to eight years, and $31 \%$, nine or more years of schooling.

Table 2 shows that fat-rich foods with highest frequency of daily intake was highest were butter or margarine (74.6\%) and milk (48.5\%). Fiberrich foods with highest frequency of daily intake were white bread (83\%) and beans (66.4\%). 
Socioeconomic, demographic, anthropometric, and dietary characteristics of the study population. 1993 Pelotas (Brazil) birth cohort study, 2004-2005 follow-up.

\begin{tabular}{|c|c|c|}
\hline Variables & $\mathbf{n}$ & $\%$ \\
\hline \multicolumn{3}{|l|}{ Sex } \\
\hline Male & 2,192 & 49.2 \\
\hline Female & 2,260 & 50.8 \\
\hline \multicolumn{3}{|l|}{ Assets index } \\
\hline $1^{\text {st }}$ quintile (lowest socioeconomic level) & 863 & 16.3 \\
\hline 2nd quintile & 851 & 16.0 \\
\hline 3rd quintile & 857 & 16.2 \\
\hline 4th quintile & 857 & 16.2 \\
\hline 5th quintile (highest socioeconomic level) & 856 & 16.1 \\
\hline \multicolumn{3}{|l|}{ Nutritional status * } \\
\hline Underweight & 313 & 7.0 \\
\hline Eutrophic & 3100 & 69.8 \\
\hline Risk of overweight & 1,029 & 23.2 \\
\hline \multicolumn{3}{|l|}{ Sedentariness } \\
\hline Yes & 2,496 & 58.2 \\
\hline No & 1,793 & 41.8 \\
\hline \multicolumn{3}{|l|}{ Maternal schooling (years) } \\
\hline $0-4$ & 1,145 & 25.9 \\
\hline $5-8$ & 1,901 & 43.1 \\
\hline$\geq 9$ & 1,368 & 31.0 \\
\hline
\end{tabular}

Note: maximum ignored values $=168$ (assets index).

* According to the World Health Organization 19.

Table 3 presents the prevalence of daily intake of fat-rich foods according to quintiles of the assets index. Frequency of intake of milk, cake, biscuits/cookies, empanadas, pastries, ham and other processed meats, mayonnaise, cheese or cream cheese, and beef roast or stakes was found to increase as family socioeconomic level increases, thus showing a positive slope index. The inverse was true for butter or margarine, chips or popcorn, eggs, French fries, bacon or sausage, and fried chicken, all of which showed negative slope indexes.

Regarding the frequency of daily intake of fiber-rich foods according to quintiles of the assets index (Table 4), we found that daily intake of fruit, green salads, other vegetables, and whole grains was directly associated with socioeconomic level, whereas an inverse association was found for white bread, beans, and potatoes.

We repeated these analyses stratifying by sex and maternal schooling (data not shown). Intake of the vast majority of foods did not differ significantly between boys and girls. Trends in terms of schooling were exactly the same as those found for the assets index.

\section{Discussion}

The present study has a cross-sectional design, since the data analyzed refer solely to the 11year follow-up of the 1993 Pelotas birth cohort Among the limitations of this study, it should be mentioned that the instrument used was not validated specifically for adolescents. A more detailed questionnaire including 80 food items was initially tested; however, data from this questionnaire was not reliable given the limited attention span of 11-year-olds. For this reason, we chose to adopt the Block questionnaire 15 .

Our results show that family socioeconomic status was significantly associated with the intake of most foods investigated. In the high-fat group, we found that frequency of intake of butter and margarine increased as socioeconomic status decreased, and that the inverse was true for milk. Considering that butter is rich in saturated fat, and that margarine is a major source of trans fat ${ }^{1}$ dietary education programs should emphasize the importance of reducing intake of these types of foods, especially to consumers in the poorest socioeconomic strata. 
Frequency of intake of foods with high fat or fiber content among adolescents. 1993 Pelotas (Brazil) birth cohort study, 2004-2005 follow-up ( $N=4,452$ adolescents).

\begin{tabular}{|c|c|c|c|}
\hline \multirow[t]{2}{*}{ Foods } & \multicolumn{3}{|c|}{ Frequency of intake (\%) } \\
\hline & Daily & Weekly & Rarely \\
\hline \multicolumn{4}{|l|}{ With high fat content } \\
\hline Butter or margarine & 74.6 & 14.8 & 10.6 \\
\hline Whole milk & 48.5 & 24.0 & 27.5 \\
\hline Cake, biscuits, empanadas, pastries & 26.6 & 56.0 & 17.4 \\
\hline Chips or popcorn & 22.2 & 55.4 & 22.4 \\
\hline Ham, processed meats & 19.1 & 42.5 & 38.4 \\
\hline Common mayonnaise & 13.8 & 39.2 & 47.0 \\
\hline Cheese or cream cheese & 11.7 & 29.3 & 59.0 \\
\hline Eggs & 9.3 & 62.3 & 28.4 \\
\hline Stake or roast meat & 7.0 & 60.3 & 32.7 \\
\hline French fries & 4.3 & 48.0 & 47.7 \\
\hline Bacon or sausage & 4.1 & 25.8 & 70.1 \\
\hline Hot dog & 2.6 & 35.5 & 61.9 \\
\hline Fried chicken & 2.4 & 45.0 & 52.6 \\
\hline Ice cream & 2.2 & 41.9 & 55.9 \\
\hline Hamburger, cheeseburger, steak sandwich & 1.0 & 21.0 & 78.0 \\
\hline \multicolumn{4}{|l|}{ With high fiber content } \\
\hline White bread & 83.0 & 15.2 & 1.8 \\
\hline Beans & 66.4 & 25.4 & 8.3 \\
\hline Fruit, excluding fruit juice & 29.9 & 59.7 & 10.4 \\
\hline Other vegetables & 11.8 & 49.8 & 38.5 \\
\hline Green salads & 11.8 & 38.2 & 50.1 \\
\hline Potatoes & 7.6 & 81.7 & 10.6 \\
\hline Natural orange juice & 6.3 & 33.8 & 59.9 \\
\hline Whole grains & 2.0 & 12.6 & 85.3 \\
\hline Whole-wheat or rye bread & 1.9 & 7.2 & 90.9 \\
\hline
\end{tabular}

Note: maximum number of ignored values $=7$.

The low frequency of milk intake $(29.5 \%)$ among adolescents from lower socioeconomic strata should also be carefully analyzed. Other studies have found similar trends among adolescents. In 2003, Enns et al. 20 showed that intake of liquid milk is decreasing among United States adolescents, being replaced primarily with soft drinks. Results from the latest Brazilian Household Budged Survey (POF) show that intake of dairy products increases with family income 21 .

Among fiber-rich foods, white bread and beans showed the highest intake levels. Beans, a traditional Brazilian dish 12 and an important source of fiber, seem still to be in favor among the population of lower socioeconomic status. This healthy dietary habit is likely to be maintained given the access of the population to this food, which is still relatively inexpensive.
Also worthy of note is the low frequency of intake of fruit (29.9\%), vegetables (11.8\%), and green salads $(11.8 \%)$ among the studied population, and especially among the poor. Surveys conducted in the United States 22 and Spain 23 also show that the socioeconomic level of parents is directly associated with intake of fruit and vegetables among adolescents. Likewise, results from the 2003-2004 POF 21 show a direct effect of family income on household availability of fruit and vegetables also in Brazil. On the other hand, we found that fruit and vegetable intake is low even among the rich, which suggests that this is not only an economic issue, but also one of habit.

There is growing evidence for a protective effect of adequate intake of fruit and vegetables against cardiovascular disease and many types of cancer 1 . In 2005, Lock et al. 24, in an analysis of 
Table 3

Frequency of daily intake of foods with high fat content among adolescents, according to assets index. 1993 Pelotas (Brazil) birth cohort study, 2004-2005 follow-up ( $\mathrm{N}=4,452$ adolescents).

\begin{tabular}{|c|c|c|c|c|c|c|c|}
\hline \multirow[t]{4}{*}{ Food } & \multirow{2}{*}{\multicolumn{5}{|c|}{$\begin{array}{l}\text { Frequency (\%) of daily intake } \\
\text { Quintiles of the assets index }\end{array}$}} & \multirow[t]{4}{*}{$\mathrm{p}$-value * } & \multirow{4}{*}{$\begin{array}{l}\text { Slope index } \\
\text { of inequality }\end{array}$} \\
\hline & & & & & & & \\
\hline & \multirow{2}{*}{$\begin{array}{c}1 \text { st } \\
\text { (lowest) }\end{array}$} & $2^{\text {nd }}$ & 3 rd & $4^{\text {th }}$ & \multirow{2}{*}{$\begin{array}{l}5^{\text {th }} \\
\text { (highest) }\end{array}$} & & \\
\hline & & & & & & & \\
\hline Butter or margarine & 74.2 & 81.6 & 81.2 & 77.2 & 59.8 & $<0.001$ & -0.17 \\
\hline Whole milk & 29.5 & 41.8 & 46.4 & 59.8 & 68.5 & $<0.001$ & 0.48 \\
\hline Cake, biscuits, empanadas, pastries & 21.5 & 23.4 & 25.0 & 30.9 & 32.7 & $<0.001$ & 0.15 \\
\hline Chips or popcorn & 22.4 & 25.7 & 25.8 & 23.2 & 13.1 & 0.01 & -0.11 \\
\hline Ham, processed meats & 11.8 & 12.4 & 18.1 & 24.9 & 28.9 & 0.02 & 0.23 \\
\hline Common mayonnaise & 8.5 & 11.3 & 14.5 & 17.0 & 18.6 & $<0.001$ & 0.13 \\
\hline Cheese or cream cheese & 3.6 & 4.5 & 7.9 & 14.0 & 29.4 & $<0.001$ & 0.31 \\
\hline Eggs & 13.7 & 9.5 & 10.0 & 7.0 & 4.7 & $<0.001$ & -0.10 \\
\hline Stake or roast meat & 3.7 & 4.3 & 6.9 & 6.5 & 14.0 & $<0.001$ & 0.11 \\
\hline French fries & 6.3 & 4.5 & 4.1 & 4.1 & 2.3 & $<0.001$ & -0.04 \\
\hline Bacon or sausage & 4.1 & 5.2 & 5.0 & 3.6 & 2.5 & $<0.001$ & -0.02 \\
\hline Hot dog & 3.5 & 2.4 & 2.5 & 2.2 & 2.2 & 0.32 & -0.01 \\
\hline Fried chicken & 3.0 & 3.8 & 2.8 & 1.8 & 0.9 & $<0.001$ & -0.03 \\
\hline Ice cream & 1.7 & 1.9 & 2.9 & 1.9 & 2.5 & 0.37 & 0.01 \\
\hline Hamburger, cheeseburger, steak sandwich & 1.2 & 1.2 & 1.2 & 0.9 & 0.7 & 0.29 & -0.01 \\
\hline
\end{tabular}

* $\mathrm{p}$-value for linear trend.

Table 4

Frequency of daily intake of foods with high fiber content among adolescents, according to assets index. 1993 Pelotas (Brazil) birth cohort study, $2004-2005$ follow-up ( $N=4,452$ adolescents).

\begin{tabular}{|c|c|c|c|c|c|c|c|}
\hline \multirow[t]{4}{*}{ Food } & \multirow{2}{*}{\multicolumn{5}{|c|}{$\begin{array}{l}\text { Frequency (\%) of daily intake } \\
\text { Quintiles of the assets index }\end{array}$}} & \multirow[t]{4}{*}{$\mathrm{p}$-value * } & \multirow{4}{*}{$\begin{array}{l}\text { Slope index } \\
\text { of inequality }\end{array}$} \\
\hline & & & & & & & \\
\hline & \multirow{2}{*}{$\begin{array}{c}1 \text { st } \\
\text { (lowest) }\end{array}$} & \multirow[t]{2}{*}{$2^{\text {nd }}$} & \multirow[t]{2}{*}{$3^{\text {rd }}$} & \multirow[t]{2}{*}{$4^{\text {th }}$} & \multirow{2}{*}{$\begin{array}{l}5^{\text {th }} \\
\text { (highest) }\end{array}$} & & \\
\hline & & & & & & & \\
\hline White bread & 85.2 & 86.4 & 87.3 & 84.7 & 70.7 & $<0.001$ & -0.15 \\
\hline Beans & 77.6 & 74.6 & 71.3 & 64.9 & 41.7 & $<0.001$ & -0.40 \\
\hline Fruit, excluding fruit juice & 22.7 & 28.6 & 30.4 & 35.3 & 32.9 & $<0.001$ & 0.14 \\
\hline Other vegetables & 8.5 & 12.6 & 10.7 & 12.5 & 14.8 & 0.01 & 0.06 \\
\hline Green salads & 7.7 & 11.9 & 10.4 & 13.9 & 15.5 & $<0.001$ & 0.09 \\
\hline Potatoes & 8.8 & 10.1 & 5.8 & 7.0 & 5.8 & 0.02 & -0.05 \\
\hline Natural orange juice & 6.0 & 5.9 & 5.8 & 6.3 & 7.9 & 0.11 & 0.02 \\
\hline Whole grains & 0.6 & 1.6 & 1.4 & 1.9 & 4.9 & $<0.001$ & 0.05 \\
\hline Whole-wheat or rye bread & 1.7 & 1.6 & 1.3 & 1.9 & 2.9 & 0.08 & 0.01 \\
\hline
\end{tabular}

* $\mathrm{p}$-value for linear trend.

the global burden of disease attributable to insufficient intake of fruit and vegetables, concluded that daily intake of these foods could reduce by $1.8 \%$ the global burden of disease, and by $31 \%$ that of ischemic cardiopathy.
Various authors 6,25 support the notion that increasing supply and cutting cost would play an important role in encouraging intake of certain foods. In 2007, Claro et al. 25, analyzing data from the 1998-1999 POF, found that reducing fruit and 
vegetable prices could have a positive effect on the participation of these foods in the diet of São Paulo population. According to these authors, a $10 \%$ reduction in the price of fruit and vegetables would lead to a $2 \%$ increase in their participation in total calorie intake.

A comparison of our findings with some of the recommendations made in a guide issued by the Brazilian Ministry of Health entitled "Healthy Eating for All: Follow the Ten Steps" [Alimentação Saudável para Todos: Siga os Dez Passos] 26 showed that certain recommendations are far from being fulfilled. For instance, daily intake of at least three portions of vegetables and another three of fruit is far from being followed by rich and poor adolescents alike. Another recommendation entails eating rice and beans every day, or at least five times a week. In our sample, we found that subjects of lower socioeconomic status were closer to fulfilling this recommendation. Frequency of daily intake of beans among the poor (77.6\%) was almost twice that found among the rich $(41.7 \%)$.

The recommended daily intake of three portions of milk or dairy and one portion of meat, poultry, fish, or eggs was followed more frequently by adolescents of high socioeconomic status, possibly due to the higher cost of these foods. Regarding the recommendation to "...avoid eating industrialized foods with too much salt (sodium), such as hamburgers, salted meats, sausages, ham, chips, preserved vegetables, and ready-made soups, sauces, and seasoning" 26 , we found higher frequency of intake of ham and processed meats among adolescents of higher socioeconomic status. Poorer adolescents showed higher intake of chips or popcorn, bacon, and sausage. However, when all these foods are analyzed as a group, intake was lower among poorer adolescents, possibly due to cost.

Regarding the recommendation to "Avoid soft drinks and industrialized juice, cakes, biscuits, sweets, desserts, and other snacks..." 26, we also found higher intake of cake, biscuits, empanadas, and pastries among adolescents of higher socioeconomic level, whereas intake of the remaining items in this group was equivalent across all socioeconomic strata. These results are consistent with the higher prevalence of overweight and obesity among adolescents of higher socioeconomic level, both in our cohort 27 and at the national level (2002-2003 POF) 28.

Even though we found a strong association between socioeconomic status and intake of certain foods, it is important to emphasize the fact that individual variables are insufficient for grasping the complexity of a phenomenon such as diet. Dietary habits are part of a context that includes cultural, economic, political, and geographical aspects. In the studied age group, food intake was inadequate among all socioeconomic strata, even the richest. It is thus important to emphasize public policies targeting the determinants of intake of fruit, vegetables, and fatrich foods. Additionally, educational measures should be implemented to induce a change in individual behavior among adolescents. Such policies should include initiatives promoting the production of healthy foods at low prices, proper labeling of foods, and control of advertisements encouraging the intake of foods with high energy density.

\section{Resumo}

O estudo descreve alimentos consumidos por adolescentes pertencentes à coorte de nascimentos de 1993 de Pelotas, Rio Grande do Sul, Brasil, conforme o nível socioeconômico. Foi feita uma análise transversal com dados coletados no acompanhamento de 2004-2005. A freqüência alimentar no último ano foi avaliada pelo questionário Block. A posição socioeconômica foi verificada com base no índice de bens, dividido em quintis. Os alimentos mais consumidos diariamente foram: pão branco (83\%), manteiga ou margarina (74,6\%), feijão $(66,4 \%)$ e leite $(48,5 \%)$. O consumo de manteiga ou margarina, pão e feijão foram mais freqüentes entre adolescentes pertencentes ao primeiro (menor) quintil do índice de bens, e o consumo de leite foi maior no último quintil. Frutas, vegetais e salada verde tiveram baixo consumo principalmente entre os mais pobres. Todos os grupos socioeconômicos apresentaram consumo elevado de alimentos ricos em gordura e baixo consumo de alimentos ricos em fibra.

Ingestão de Alimentos; Hábitos Alimentares; Fatores Socioeconômicos; Adolescente; Estudos de Coortes 


\section{Contributors}

M. B. Neutzling, C. L. Araújo, P. C. Hallal, and A. M. B. Menezes participated in analysis and data interpretation; in the writing of the manuscript, and in the critical review of the intellectual content, and approved the final version. M. F. A. Vieira collaborated with writing the manuscript and in the critical review of intellectual content, and approved the final version. C. G. Victora reviewed the manuscript and participated in the writing of the final version of the manuscript.

\section{Acknowledgments}

The cohort study is supported by the Wellcome Trust. The initial stages of the cohort study were supported by the European Union, the Brazilian National Program for Centers of Excellence (PRONEX), the National Research Council (CNPq), and the Brazilian Ministry of Health.

\section{References}

1. World Health Organization; Food and Agriculture Organization. Diet nutrition and the prevention of chronic diseases. Report of a Joint WHO/FAO. Geneva: World Health Organization; 2003. (WHO Technical Report Series, 916).

2. Ness AR, Maynard M, Frankel S, Smith GD, Frobisher C, Leary SD, et al. Diet in childhood and adult cardiovascular and all cause mortality: the Boyd Orr cohort. Heart 2005; 91:894-8.

3. Mikkilä V, Räsänen L, Raitakari OT, Pietinen $P$, Viikari J. Longitudinal changes in diet from childhood into adulthood with respect to risk of cardiovascular diseases: The Cardiovascular Risk in Young Finns Study. Eur J Clin Nutr 2004; 58:1038-45.

4. Irala-Estévez JD, Groth M, Johansson L, Oltersdorf U, Prättälä R, Martínez-González MA. A systematic review of socio-economic differences in food habits in Europe: consumption of fruit and vegetables. Eur J Clin Nutr 2000; 54:706-14.
5. Sanchez-Villegas A, Martínez JA, Prättälä R, Toledo E, Roos G, Martínez-González MA, et al. A systematic review of socioeconomic differences in food habits in Europe: consumption of cheese and milk. Eur J Clin Nutr 2003; 57:917-29.

6. Giskes K, Turrell G, Patterson C, Newman B. Socio-economic differences in fruit and vegetable consumption among Australian adolescents and adults. Public Health Nutr 2002; 5:663-9.

7. Serra Majem L, Ribas Barba L, Pérez Rodrigo C, Roman Viñas B, Aranceta Bartrina J. Hábitos alimentarios y consumo de alimentos en la población infantil y juvenil española (1998-2000): variables socioeconómicas y geográficas. Med Clin (Barc) 2003; 121:126-31.

8. Neutzling MB, Araújo CLP, Vieira MFA, Hallal PC, Menezes AMB. Freqüência de consumo de dietas ricas em gordura e pobres em fibra entre adolescentes. Rev Saúde Pública 2007; 41:336-42. 
9. Nunes MMA, Figueiroa JN, Alves JGB. Excesso de peso, atividade física e hábitos alimentares entre adolescentes de diferentes classes econômicas em Campina Grande (PB). Rev Assoc Med Bras 2007; 53:130-4.

10. Sichieri R, Castro JFG, Moura AS. Fatores associados ao padrão de consumo alimentar da população brasileira urbana. Cad Saúde Pública 2003; 19 Suppl 1:S47-53.

11. Willet W. Nutritional epidemiology. 2nd Ed. New York: Oxford University Press; 1998.

12. Coordenação-Geral da Política de Alimentação e Nutrição, Secretaria de Atenção à Saúde, Ministério da Saúde. Guia alimentar para a população brasileira Brasília: Ministério da Saúde; 2005.

13. Sichieri R. Epidemiologia da obesidade. Rio de Janeiro: EdUERJ; 1998.

14. Victora CG, Araújo CLP, Menezes AMB, Hallal PC Vieira MF, Neutzling MB, et al. Methodological aspects of the 1993 Pelotas (Brazil) birth cohort study. Rev Saúde Pública 2006; 40:39-46.

15. Thompson FE, Byers T. Dietary assessment resource manual. J Nutr 1994; 124(11 Suppl):2245S317S.

16. Araújo CL Menezes AMB, Vieira MFA, Neutzling MB, Gonçalves H, Anselmi L, et al. The 11-year follow-up of the 1993 Pelotas (Brazil) birth cohort study: methods. Cad Saúde Pública 2010; 26 : 1875-86.

17. Mackenbach JP, Kunst AE. Measuring the magnitude of socio-economic inequalities in health: an overview of available measures illustrated with two examples from Europe. Soc Sci Med 1997; 44: 757-71.

18. World Health Organization. Physical status: the use and interpretation of anthropometry. Report of a WHO Expert Committee. Geneva: World Health Organization; 1995. (WHO Technical Report Series, 854).

19. Biddle S, Cavill N, Sallis J. Young and active? Young people and health-enhancing physical activity: evidence and implications. London: Health Education Authority; 1998.
20. Enns C, Mickle S, Goldman J. Trends in food and nutrient intakes by adolescents in the United States. Family Economics and Nutrition Review 2003; 15:15-27.

21. Levy-Costa RB, Sichieri R, Pontes NS, Monteiro CA. Disponibilidade domiciliar de alimentos no Brasil: distribuição e evolução (1974-2003). Rev Saúde Pública 2005; 39:530-40.

22. Xie B, Gilliland FD, Li YF, Rockett HR. Effects of ethnicity, family income, and education on dietary intake among adolescents. Prev Med 2003; 36: 30-40.

23. Aranceta J, Pérez-Rodrigo C, Ribas L, Serra-Majem L. Sociodemographic and lifestyle determinants of food patterns in Spanish children and adolescents: the enKid study. Eur J Clin Nutr 2003; 57 Suppl 1:S40-4.

24. Lock K, Pomerleau J, Causer L, Altmann DR, McKee M. The global burden of disease attributable to low consumption of fruit and vegetables: implications for the global strategy on diet. Bull World Health Organ 2005; 83:100-8.

25. Claro RM, Carmo HCE, Machado FMS, Monteiro CA. Renda, preço dos alimentos e participação de frutas e hortaliças na dieta. Rev Saúde Pública 2007; 41:557-64.

26. Ministério da Saúde. Alimentação saudável para todos: siga os dez passos. http://dtr2004.saude. gov.br/nutricao/documentos/10passos_adultos. pdf (accessed on 09/Sep/2008).

27. Araújo CL, Dumith SC, Menezes AMB, Hallal PC, Vieira MFA, Madruga SW, et al. Nutritional status of adolescents: the 11-year follow-up of the 1993 Pelotas (Brazil) birth cohort study. Cad Saúde Pública 2010; 26:1895-903.

28. Instituto Brasileiro de Geografia e Estatística. Pesquisa de orçamentos familiares 2002-2003: antropometria e análise do estado nutricional de crianças e adolescentes no Brasil. Rio de Janeiro: Instituto Brasileiro de Geografia e Estatística; 2006.

Submitted on $05 / \mathrm{Feb} / 2009$

Final version resubmitted on 30/Sep/2009

Approved on 14/Oct/2009 